\title{
POST-APARTHEID SOUTH AFRICA'S EXACERBATED INEQUALITY AND THE COVID-19 PANDEMIC: INTERSECTIONALITY AND THE POLITICS OF POWER
}

\author{
Juliet Eileen Joseph \\ Centre for African Diplomacy and Leadership (CADL) \\ University of Johannesburg \\ Auckland Park, South Africa, PO Box 524, 2006 \\ jjoseph@uj.ac.za
}

\begin{abstract}
Over the past fifteen years there has been an increase in the number of protest movements globally. In recent years and amid the global pandemic there have been hundreds of protests and demonstrations in South Africa. Consequently, in comparison to other parts of the globe, such protest action in South Africa is high. As a result, stable governance in the region has been impacted.

Notably, during the resistance years in defiance of the apartheid regime, citizens in South Africa expressed their social discontent against exclusion and marginalisation through identities as radical and intersectional - this was also articulated in the recent protests that occurred in KwaZulu-Natal and parts of Johannesburg in July 2021. This highlights the relevance of intersectionality within this region. Intersectionality can be seen to refer to the inequalities that exist beyond femininities and masculinities. Intersectional theory explores aspects of discrimination, oppression, exploitation and inequality across identity, gender, race, ethnicity and class. This study uses a qualitative research approach to conceptually analyse intersectional theory. Thereafter the study discusses the relevance of intersectional theory in a post-apartheid context by illustrating intersectionality through the unrest and protests that occurred, following the jailing of former president Jacob Zuma. The findings of the study suggest the need to unpack the legacies of African elitism and social relations, while implementing intersectional reform that promotes greater inclusivity of citizens in the state.
\end{abstract}

Keywords: intersectionality, nationalism, Covid-19 protests, capitalism

DOI: 10.21303/2504-5571.2021.002099

\section{Introduction}

The recent protests that occurred in KwaZulu-Natal and Johannesburg following the imprisonment of former president Jacob Zuma illuminated notions of capitalism, nationalism and intersectionality. The protestors articulated their radical opinions through the use of violence, such as burning trucks and factories and looting shops [1]. These highly organised protests highlight the way, in which protests have become radical. This was articulated in the protestors' use of knobkieries, in the use of petrol to burn factories and trucks, and in the mass looting of malls and shops within close proximity of townships. In comparison to previous protests, these protests provide an existential defining moment within disadvantaged black communities in South Africa of the prevailing inequality gap between the rich and the disadvantaged, more specifically in a post-apartheid context.

The independent experiences of the protestors who formed part of the protesting communities can also be explored using the knowledge of theory. This is in line with the protestors' challenges to the intersectional oppressions and can be seen to be connected to postcolonial theory, as well as the ramifications of colonialism, such as capitalism, elitism and popular nationalism. The intersectional oppressions encompass notions of discrimination, oppression, exploitation and inequality across identity, gender, race, ethnicity and class. The intersectional identities, used by the looters, encompassed the intersectional identity of disadvantage, which exists beyond femininities and masculinities.

The theory of elite revolutions can also be explored through the knowledge of theory, which may serve as a greater representation of the events that occurred.

In the vanguard of the protests were the pro-Zuma protestors who were against the arrest of the former president. Following his imprisonment, there was an upsurge in protests, first in KwaZulu-Natal and then in parts of Johannesburg.

The evening before the start of the protests, President Cyril Ramaphosa, the current head of state, addressed the nation on the Covid-19 pandemic, highlighting that South Africa would remain under lockdown Level 4 with restrictions, such as the banning of alcohol sales and the continuing 
closure of some businesses, thus impacting on the economy. This suggests that social discontent could have also been further incited as a result of increased poverty and inequality as well as pressure on a stressed economy, thus leading to the protests. Protestors subsequently burnt trucks and factories and looted shops, affecting the supply chain through their mass mobilisation across the two provinces. These protests eventually resulted in the mass looting of malls within close proximity to townships, where the majority of the population lives.

At the start of the Covid-19 pandemic in South Africa in 2020, the state developed a stimulus package to assist businesses and the poor and disadvantaged financially with additional social grants during the tough economic times. However, this grant was not provided for the duration of the lockdown level 4 that occurred in July 2021, at the time of the protests, although it has since been reinstated. Accordingly, many were unhappy about the lack of provision of this grant during this time, as little support was available for citizens with no income or other livelihood support.

The protests were presented with a diverse group of protestors and looters; initially, in KwaZulu-Natal male protestors were seen with knobkieries and Zulu head pieces as trucks were burnt. Thereafter, mothers, fathers, children and grandmothers and grandfathers were seen to be mass looting malls, stripping the shops bare of goods. It is important to distinguish these protests from previous protests that have occurred in the post-apartheid dispensation. These differed in terms of the increased levels of violence, organised crime through looting and the mass inclusion of diverse groups of protestors and looters.

Britton and Fish's [2] sentiments hold relevance even today. They state that the post-apartheid state has fallen far short of the promises of the Reconstruction and Development Programme (RDP) for widespread access to land and housing and a secure social safety net, in part because of the donor-driven shift towards the market-based national Growth, Employment and Redistribution (GEAR) plan that offloaded much of the obligation for social welfare and development onto the private sphere of the household.

This article discusses the recent 2021 protests in KwaZulu-Natal and Johannesburg in order to contextualise the relevance of intersectional theory in the South Africa. This is done through a conceptual analysis of intersectional theory in an effort to study its relevance to the South African context through the recent protests in the post- colonial setting. This will also be done in order to determine the scope of intersectional theory with regard to a reformist nature.

The key aim, accentuating this study, is the possibility of transforming South Africa's governance architecture, by exploring intersecting oppressions for most inclusive policy reform. As has been suggested previously, intersectional theory delves into facets of marginalisation, unfairness, discrimination, and inequality across identity, gender, race, ethnicity and class. In particular, the study seeks to explore South Africa's Broad Based Black Economic Empowerment (BBBEE) programme. In short, BBBEE aims at redressing racial disparities that transpired as the result of the Apartheid regime in an effort to distribute wealth and opportunity more equally amongst the various racial groupings in South Africa. Given this, the aim of BBBEE is to improve the lives of black people, through creating greater opportunity to these citizens. The way, in which South Africa's capitalist system is organised, does not guarantee that BBBEE will impact on ensuring a more representative distribution of wealth in the country. There will however be changes that occur in this frontier where wealth is distributed to targeted individuals, impacting BBBEE quotas being reached. The paper calls for intersectional theory and intersecting oppressions to be considered as a measure in place in transformational policy reform to ensure greater inclusivity, diversity and fairness in the region.

\section{Material and Methods}

A qualitative research study was conducted. Although the notion of inequality in South Africa and social discontent has been explored in academic literature, there is little literature on these ideas in relation to intersectional theory in the South African context. Moreover, there is relatively little evidence of these nuances in recent years. The contribution of this study is related to the limited knowledge of not only the status of intersectional theory and transformational politics 
in South Africa, but also of intersectional theory under the Covid 19 pandemic in a post-liberation and democratic transition environment that requires more attention.

This study explored intersectionality and its connection to the South African transformation project through an examination of social movements and BBBEE programmes in South Africa and their outcomes in ensuring a representative distribution of wealth and opportunities for South African citizens. This study is a case study of South Africa.

The design of the study consisted of data collection and documentation with the aim of answering the questions and hypotheses. Initially, a quantitative exploratory literature review was conducted, examining definitions, theories, policies, viewpoints, principles, methods and other research findings, as well as a data collection of statistics from the various institutions. The study focused on the politics of inequality, social discontent and the relevance of intersectional theory in contemporary South Africa.

The South African BBBEE transformation framework needs to be further examined and analysed to ensure that transformational obstacles and remedies are proposed. A review of the current transformational model is urgently needed to create an enabling environment for greater inclusion, equity and transformation.

\section{Result}

\section{1. Expounding on intersectionality theory}

Intersectionality can be defined as the relationship between gender, race, class, disability and other categories of difference in multiple settings, as well as the connection and influence of the interactions between them [3]. Furthermore, Archer and Francis [4] posit that intersectional theory is also linked to power relations, focusing on elitist regimes and oppression [4], suggesting that intersecting oppressions, connected to disadvantage and inequality, exist between the affluent and the disadvantaged. Unlike feminism, but complementary to it, intersectional frameworks aim to deconstruct binary oppositions and universalism, related to identity.

Intersectional analysis can be understood to involve a combination of oppressions, which result in exploitation and inequality. Intersectionality is closely linked to social constructions and formations, which create rules for social relations and collectivise in gender representation and categories.

Kimberle Crenshaw (1989) [5], a proponent of intersectional theory, identified the triple oppression of black women in the United States along the lines of race, class and gender. Scholars, linked to intersectional theory, maintain that while it has its roots in the United States of America (USA) and is linked to postcolonialism, it is shaping human lives beyond the USA [6-9].

At the beginning, the theory separated men and women, but since this has transpired into a consolidated study. The challenge, faced by black women in the USA, is based on the premise that classical and former feminisms did not promote the interests of these women, only those of Western white females. Secondly, the concept of intersectional theory was initially constructed on the notion that environments are not static [5], meaning that the challenges black women face in the US differ from the challenges black women in South Africa confront. Importantly, this demonstrates a similar discourse to the intersecting challenges women in South Africa endure, reflecting how hegemonies exist even in the same race. In addition, the challenges, faced by affluent black women in South Africa, differ from the struggles, faced by marginalised black women. This occurs along the lines of access to resources, ownership and the income status.

Intersectional theory has led to feminisms and gendered movements that focus on the gender differences that exist in society, such as queer and transsexual theory, therefore aiming to address feminist challenges that intersect the lines of race, class, and gender. This theory has led to differences within feminism, such as postmodernist and post-structural feminism. Postmodernism focuses on the identity of politics and the deconstruction of race, gender and class issues. Post-structural feminists focus on gender problems and are criticised for their lack of attention to economic challenges [3]. This is demonstrated in the differences in oppression among marginalised South African women who lack economic buying power, demonstrating different contexts with different outcomes. This study suggests that this is mainly due to cultural stereotypes and 
generalisations, which oppress and subordinate women, directly impacting on their agency [5]. This argument has its roots in the biological differences, which exist between men and women. Such attitudes are therefore acceptable in many cultures and have become social constructs. Furthermore, gender relationships are distinguished as the result of time, space, race, class, sexuality, colonialism and space.

Ultimately, intersectionality in feminism attempted to address differences and divisions among women and men. Accordingly, this aim to transcend genders is what makes this such a unique theory [4], highlighting how gender and intersecting differences are linked to power relations. In expanding on this argument, in Africa, elitist regimes continue to have a severe impact on the security of nations, leading to a deterioration in livelihoods as a result of huge inequalities between the rich and the disadvantaged, as in the case of South Africa, and increasing levels of poverty, unemployment, and gender inequality.

Moreover, intersectional frameworks aim to deconstruct the binary oppositions and universalism, which prevail along identity lines. Foucault [3] notes that intersectional theory deconstructs representations and embraces multiculturalism and diversity, and is mainly aimed at the inclusion of the oppressed. Stewart Hall [10] posits that people construct social reality through meaning, such as the term 'Black Diamonds', which is linked to connotations of privilege, power and domination. This is accompanied by the representation of the deprived, which is linked to poverty, the poor, the marginal and the weak. Moreover, such labels and framing constructions are factors, which exacerbate classism.

The world operates as an unequal system in most spheres of society. Different levels of social division exist within different societies, along the lines of gender, class, ethnicity and sexuality. In addition, similarities, differences, categories and collectives are aligned to inequality [11].

Intersectional analysis involves a combination of oppressions, which exacerbate exploitation and inequality. Intersectionality is closely linked to social constructions and formations, which create rules for social relations and collectivise in gender representation and categories. This goes beyond gender, race and class to include disability, religion and sexuality [11].

McDowell [5] notes that owing to changes in the balance of power, theorists in international relations have revisited orthodox theory and approaches to understand the social, political and economic changes, taking place around the globe. Intersectional analysis holds relevance as it is a new concept, which emerged as a result of differences that exist along the lines of gender, race and class [3] and economic oppression. In South Africa, it remains relevant as this inequality exists within a capitalist system, which exploits and divides, creating an environment for some to have more than others [12].

Intersectional theory differs from feminism, as intersectional approaches are diverse in context and time. Intersectional theory embraces diversity as opposed to universality, which accommodates different contexts and situations [5]. The disadvantaged black population in South Africa, like the disadvantaged black population in the United States, faces the challenges of triple oppression, even though they have dissimilar challenges and are unlike their economically, politically and socially empowered black elite counterparts. Black feminists argue against privilege over others, while embracing diversity and difference. This demonstrates that unequal societies exist and can be seen to be linked to class differences in both the developed and the developing worlds. Ensuring that the interests of the poor masses are tackled in decision-making processes, which are often driven by the privileged, therefore remains a challenge [13].

In South Africa, this paradox prevails in the presence of a small white capitalist elitist network and the privileged emerging black middle class who make up the middle-income group in South Africa. This group, often referred to as the "Black Diamonds", remains a powerful network of the black middle-income group that has been privileged by capitalism. This group occupies the higher Living Standards Measures (LSM), hence they form part of the upper class structures. In addition, men can be seen to have more authority and power in various sectors of society as the result of their influence and economic power, which prevail due to patriarchy and male domination. On the other hand, their disadvantaged counterparts remain in the lower LSM levels, forming part of the lower class structures and have less influence and economic power. These differences can be 
seen to exist as the result of patriarchy and male domination, cultural and religious stereotypes and also as the result of historical legacies [5]. Hence, multiple intersecting oppressions can contribute and are aligned to the master intersection identities (eg, gender), and emergent identities (i. e., black lesbian) [14]. Having children impacts on a woman's income and status, level of employment, education, societal and cultural frames and stereotypes.

For the purpose of this article, social theories like intersectional theory link unexpected events, unlike other theories, which are based on predictions. In expanding on this argument, intersectional theory creates a differing trajectory, which is based on emerging experiences and not a new theory altogether. A typical example of this can be seen to be connected to emerging human security challenges that impact on black people's continued marginalised in connection to adequate access to basic services, such as water, sanitation and refuse [15-18]. These failures and disadvantages disproportionately affect not only black people but black women are the ones most affected [19-21]. Furthermore, [22] posit that public services, needed within households, such as water and sanitation services, are conceivably resistant to gender-specific legislative and policy recommendations, this is due to the sexual division of labour within the households, where women take on the role of managing water supplies for cooking, cleaning and experience intersecting challenges in accessing water and sanitation.

This can be seen to be connected to intersecting oppressions along the lines of race, class and gender, alerted to an oppressive and exploitative manner [3]. This theory hold relevance for this study as it has contributed to and tackled the constraints of universalism, which is linked to representations and categories, distributing unequal power relations. Often referred to as intersectional analysis, this theory has helped feminists overcome cultural bias and differences in bridging the gap between generalist and specialist thought systems. The generalist view argues that theory is based on classical thought and they devote time to understand parts of the theory. In contrast, the specialist view understands theory as a whole. Therefore, intersectionality appeals to generalists and specialists, and identifies how differences intersect in personal identity, social practice and/or location [3].

The above section suggests that intersectional theory explores identity categories and salient differences in connection to intersecting oppressions that impact on the degrees of exclusion, vulnerability, empowerment or access to resources [3]. The protests, discussed in this article, comprised of a diverse group of black people, identifying the intersecting oppressions, and identified the similarities, revealed a connection to disadvantage, and all of the protestors were people of colour, suggesting that race, class and gender formed part of the intersecting oppressions in this regard.

\section{2. Intersectional framework and its relevance in a democratic South Africa: a plu-} ralist state

In reflecting on intersectional analysis, the demise of the apartheid regime and new policies, such as Broad Based Black Economic Empowerment (BBBEE), interrelated categories complement each other within the public and private as well as organisational and institutional domains. It is for this reason, that there remains the oppression, exploitation and exclusion of some, economic freedoms particularly remain unfair and unequal, even within the hegemonies of the black population groups. There has been a move to address this, although the changes have been parochial and insubstantial due to a lack of sufficient literature available on this topic.

Intersectionality is a concept that emerged in the 1980s and is evolving as a result of various researches, conducted in different locations and at different times. Davis [3] defines intersectionality as "the interaction between gender, race and other categories of difference in individual lives, social practices, institutional arrangements, and cultural ideologies and the outcomes of these interactions in terms of power".

\section{3. The emergence of a black bourgeoisie and the triple bottom-line repression}

In Lindiwe Mabuza's [23] book titled One never knows: An anthology of black South African women writers in exile, she articulates the relevance of the triple oppressions, connected to inter- 
sectional theory, and highlights that South African women's real freedom would transpire from the liberation movement in support of men. This can also be seen to hold relevance for the people in South Africa.

The idea of a South African black bourgeoisie was crafted by the former democratically elected president of South Africa, Thabo Mbeki. During his tenure, policy and legislation was instituted in order to overcome poverty and the growing inequality gap, so that people of colour could build economic capital in a society, dominated by a small middle-income group and foreign white capital as drivers of the economy. This black economic capital would be attained through the BBBEE legal framework, positioning black citizens to acquire entry into the economy through government contracts and procurement policies; privatisation and re-structuring programmes; regulating resources; business licences and quotas; investment credit and a black capitalistic market; and land redistribution programmes were enshrined in legislation and law [24].

However, strict rules centred on ownership, skills development, income and participation would form the basis of success [25] for a thriving black petit bourgeoisie. Ultimately, BBBEE would fulfil the strategic direction and roadmap, tackling prevailing human security challenges, such as unemployment, equity and access to services [26]. This new middle class would directly impact on nationalist discourses and propel social transformation and racial unity in order to create 'patriotic' capital, which would produce development and progress for the poor masses [13].

Today, many claim that this black middle-income group live lavish lifestyles, recklessly spending money, as opposed to assisting the poor masses by ploughing money back into townships. Gumede [27] notes this has been exaggerated and the middle-income black elitist groups have not progressed as fast due to their small numbers and the slow growth of black business establishments who operate with limited capital accumulation challenges and market volatility impacts on their existence. One may suggest that the middle-income status of this group has not secured their entry into predominantly white dominated markets. On the contrary, Moeletsi Mbeki [28], the brother of the former president of South Africa, Thabo Mbeki, argues that the political elite took over African states at independence and saw the state as a means to serve their self-enrichment and accumulation of privilege and not for the mass population. Hence, the challenges might not be linked to the formation of a black middle-income group, but rather the elite that form part of the state or rather the challenges, linked to patrimonial politics.

This study concurs with Moeletsi Mbeki [28] that the elite minority in power are responsible for current protests and regression within the region, owing to their failure to limit further disadvantage for the disadvantaged amidst the global pandemic, further exacerbating the intersecting oppressions, faced by the poor and vulnerable.

It is for this reason, that social discipline becomes an important aspect for development. This can be connected to the idea that privileged powers ensure states fall into this category and become chaotic due to social discontent, as a result of corruption and a lack of delivery, causing instability and making them turbulent in nature [13]. As a result, South Africa remains systematically saturated and structural challenges continue to prevail, reinforcing a type of capitalism, which does not serve the vast majority of poor people [28].

BBBEE strategies have also not ensured growth in black-owned business and tenders. Procurement and privatisation policies have raised contention owing to unauthentic multiracial businesses and the fronting of black ownership in businesses to gain access to government tenders [25]. In addition, politicians have turned businessmen and businessmen have turned politicians, as exemplified by the current South Africa president, Cyril Ramaphosa, as well as Tokyo Sexwale and Mathews Phosa, who form part of this privilege, which has transcended to family ties and patrimonial politics, notwithstanding the state instituted policy on political affiliations and business interests introduced in 1999. Civil society actors, such as the general secretary of the Congress of South African Trade Unions (COSATU) under the Mbeki Administration, Zwelinzima Vavi, and Desmond Tutu, and in recent years more public figures, have publicly criticised minority privilege and self-accumulation at the expense of mass dispossession.

In addition, South Africa's high income earners remain Anglo-Saxon white males, suggesting the composition of economic diversity in South Africa has not changed and the lowest paid 
citizens remain disadvantaged black citizens. This suggests that instances of income remain linked to privilege, regardless of BBBEE policy meant to bridge inequalities, connected to South Africa's unequal society [26]. This means that even if black people acquire expertise, they would still not gain entry to top positions owing to the privilege and nepotism that plague South Africa. This is a major concern, which requires further investigation in order to overcome intersecting oppressions.

In exploring classism as an intersecting oppression for black people, this workforce in the formal labour market comprises of black management, senior black management and black entrepreneurs. Despite these well-crafted policies and advances in legislation, the continued trend of class, race and gender unfairness in corporate South Africa prevails [29]. This can be seen to be connected to the gender unfairness challenges, where women are more likely to be underemployed in comparison to men in the formal economy [30,31], being able to secure work within corporate South Africa and the economy [32,33], secondly receiving the same and/or fair remuneration in comparison to their male counterpart [30, 34-36] and lastly being able to progress in their careers once in South Africa and the formal economy [37-39]. These intersecting oppressions, when exploring intersectionality suggests a gender gap the low proportion of women to men in leadership [40, 41]. In 2016, $39 \%$ (107) of the 278 of South Africa's municipalities were female [42].

Women constitute of 51 percent of the population and 58 percent of voters, yet the number of women candidates in local government elections is still lower than 50 percent representation in comparison to that of men [42]. Fajardo (2017) [43] states that $31 \%$ of South African organisations have no female representation in senior management roles. The same can be said to exist in South Africa's local government sector. Hence, women are not equally represented in municipal government. If women then constitute of more than half of the population and remain underrepresented as decision takers, it becomes questionable who is driving women's issues or rather their agenda. From a leadership perspective women are still underrepresented as leaders in corporate South Africa across different sectors and also in the public sector. Makgetla [44] notes that, in some instances companies suggest that disadvantaged people, despite having the correct skillset, might not be the correct culture fit, highlighting undertones of classism.

The ANC-led strategy for economic development favours international and local capital, benefitting other layers, such as the 'African petit bourgeoisie' and the working class. This is articulated in policy amendments and has been implemented in the Labour Relations Act, the Employment Equity Act, the Basic Conditions of Employment Act and the Broad Based Black Economic Empowerment (BBBEE) Act and reaffirms African nationalistic ideology in state transformation.

It is important to remember, that the Marxist project in South Africa saw people's liberation as a necessity and believed that this would inevitably occur as the result of social transformation in society. This was as a result of the agreement between state and capitalists and directly 'betrays' the plans of the socialist movement that played a major role in overcoming the oppressive apartheid regime [13]. In South Africa, privilege is associated with money, prestige and material accumulation. This is demonstrated in the lavish lifestyles of the elite and consumer studies that focus on the spending trends of the mass population [13]. Mbeki [28] notes the focus at inception was not on creating a parasitic elitist network dependent on state funding or for the personal accumulation of wealth, but in order to ensure a snowball effect, which impacts on all black South Africans. Even though contentions reside, the black bourgeoisie symbolises that change can inevitably transpire over time due to structural change and plans, connected to economic recovery.

With increased levels of joblessness and unemployment as the result of the global pandemic [45] high unemployment, the migrant labour system and the difficulties, facing the informal sector, will continue to hit the poor particularly hard.

In retrospect, Abbas and Mama in House Africa [46] argue that the new ruling elite are the ones who engrained patriarchal authority, and this is what led to feminist movements, focusing their attention and efforts on liberal norms, values and principles, linked to Pan-African ideals, which are inclusive of all people on the continent. This can be attested to in South Africa's first peace talks and negotiations, at which no women were present or represented. In fact, the elite steered the process, which was focused on the ANC party particularly [47]. Furthermore, the negotiation pro- 
cess was regularly convened and negotiated by men, and it was linked to the party structure, which allowed senior party members, who remained men, to undertake the reconciliatory talks [48].

Since independence, South Africa has been plagued by emerging human security threats, which have been even further exacerbated by the Covid-19 pandemic and include increased unemployment, lack of access to education and the growing divide between the rich and poor. This has led to privilege for some and deprivation for others. As a result, the security of South Africa remains compromised. Privilege and classism are as old as human existence and will continue to remain well into the future. The main purpose of this study confirms that the transition processes, systems and legacies of the past, linked to South Africa's apartheid regime, continue to dominate the state within the domains of gender, class and race. In addition, privilege remains a security threat for the vast majority of the population due to the growing divide between the rich and poor, which affects the livelihoods of the majority of the population.

The World Bank findings [48] concur that many African poor will fall into extreme poverty as the result of the global recession and the Covid-19 pandemic. This is due to inequalities along the lines of income, ownership and access; in addition the poor lack the capital, required to gain more resources. Coincidentally, there is a direct correlation and different degrees of inequality within population groups. The lives of a minority group of black privileged people have changed for the better in post-apartheid South Africa.

The mounting human security challenges demonstrate that policies have not been successful, as human security challenges, such as unemployment, gender inequality and the growing divide between rich and poor, continue to prevail. This is mainly as a result of race, class and gender challenges. The status quo remains, as the true challenges, related to insecurity, gender inequality and privileged hegemonies, remain under-explored. Intersectional theory aims to tackle social injustice, which is based on privilege within class, race, gender and ethnicity. In the South African context, there is a need to revisit the racialisation process in order to ensure there are not a minority of winners and a majority of losers. Tackling notions of 'otherness' and privilege, allowing for divide and rule, should be employed.

Recent research has shown that the black middle class has grown, but it has remained fairly small and timid. In South Africa's former years, the black ownership share was less than $15 \%$ of the economy. In 2019, the black ownership share of the economy was $29 \%$, as opposed to $25 \%$ in 2018 and $32 \%$ in 2016 [49]; prior to that $15 \%$ of the economy was owned by black people. This, despite the fact that black South Africans comprise $90 \%$ of the population. Notably, there is no sector within the economy that has more than $50 \%$ black ownership with the black share, amounting to only $12.1 \%$ in large entities.

Further to this and in explaining the inequality within the region, Statistics South Africa [20] highlight that the loss of income, resulting from the Covid-19 pandemic, can lead to higher levels of food insecurity and hunger. In hindsight, BBBEE is meant to bridge the inequality gap that exists economically between black and white people in South Africa, even though the livelihoods of both poor black and white people are at stake and the BBBEE policy does not serve the vast majority. The interests of the majority of the citizens must be taken into consideration as South Africa remains a ticking time bomb due to discontent and resentment by the groups that remain marginalised. Policies must extend beyond skin colour and class, ensuring true innovation and change for the livelihoods of all in the state.

It is worth noting, that during South Africa's transition to an interim Government of National Unity, gender activists pushed hard for socioeconomic and reproductive rights to lay the foundation for affirmative action through the Constitution, in order to institutionalise social citizenship. The ANC further brokered social justice through the transition period and the Constitution [48].

However, in 2012 Patel and Graham [51] posited that women were the ones who were beginning to benefit from BBBEE through social development funds. This may hold relevance for the current protests, as they were sparked just after the president's speech, which announced that the country would remain on tight lockdown level 4 without any social grant provision for the vulnerable and poor who do not earn an income. 
In recent years, more studies on the impact of BBBEE and how it has contributed to social development as the result of business compliancy to the policy are needed. However, this does not resolve the issue of fairness and equality for all citizens of the state, particularly for poor Africans to gain full entry into the markets [51]. The businesses that have resulted from BBBEE have not created jobs for the majority, even though inclusion programmes have been instituted. Hence, BBBEE programmes have led to only certain representatives of the black population gaining entry as opposed to re-structuring capitalism to favour the majority

However, BBBEE policy has delivered on its strategy to create a black capitalistic class or business elite to complement white capitalists in South Africa in order to ensure a consumer boom and economic development. Importantly, this type of equality remains flawed and is based on a group of privileged black South Africans and not the individual identity alone. The majority of South Africans have not benefitted nor has poverty been reduced for the majority of black people in the region.

\section{Conclusion}

This article conceptualised intersectionality through the politics of exclusion and domination in the South African postcolonial context. Political inclusiveness should be understood and applied not merely in terms of quantity but, more importantly, in terms of the quality of interest representation by office holders. The black middle class has become a reality in South Africa, promoting multiculturalism. The powerful groups can continue to contribute to multiculturalism and economic development, which has an impact on social development, as long as there is a clear separation between state and elitist power. Evidence suggests that following the demise of apartheid South Africa, focus was placed on global economics as opposed to development issues and this impacted on the lives of people within the region. In South Africa, when the ANC government came into power in 1994, the capitalists diverted from supporting immediate economic change for the majority of the population who are black people, this led to a salient political and economic crisis. In addition this secured minority gains and capitalistic position, ultimately highlighting concerns about the effectiveness of neo-liberal programmes.

This also led to capitalistic domination, which not even the ANC could direct, due to the pre-existing dominant capitalistic order [23]. Furthermore, black subordination prevails within white-dominated capitalism. Human security and the creation of better living conditions remains very important for the wellbeing of all citizens, and just as important is increasing their share of the global economy.

At present, BBBEE has not de-racialised South Africa; it serves a small minority of people, which includes white capitalists who are both local and foreign, as well as an emerging black middle-income group. Hence, the economy is still dominated by a minority, while the majority continues to be marginalised. Thus, the relationships between the social conditions and cultural legacies of African elitism need to be unpacked and there is a grave need for intersectional reform, which is inclusive for all citizens in the state.

Notably, exclusionary policies; re-racialisation and privileged capitalism, corruption; and a lack of self-regulation have led to nepotism, which reinforces resource accumulation and power. The stark reality is that $90 \%$ of the population remain deprived of the privileges, enjoyed by the minority, hence contentious and questionable. BBBEE favours the privileged over mass development and is based on a system of inclusion in resources, access and income.

\section{References}

[1] Drury, F. (2021). South Africa riots: Looting and shooting in Durban. BBC news. Available at: https:/www.bbc.com/news/ world-africa-57822460

[2] Britton, H., Fish, J. (2008). Engendering Civil Society in Democratic South Africa. Working Across Divides. Scottsville: University of KwaZulu-Natal Press.

[3] Davis, K. (2008). Intersectionality as buzzword. Feminist Theory, 9 (1), 67-85. doi: http://doi.org/10.1177/1464700108086364

[4] Archer, L., Francis, B. (2006). Understanding Minority Ethnic Achievement: Race, Gender, Class And 'Success'. London: Routledge, 224. doi: http://doi.org/10.4324/9780203968390 
[5] McDowell, L. (1991). The baby and the bath water: Diversity, deconstruction and feminist theory in geography. Geoforum, 22 (2), 123-133. doi: http://doi.org/10.1016/0016-7185(91)90002-8

[6] Bunjun, B. (2010). Feminist Organizations and Intersectionality: Contesting Hegemonic Feminism. Atlantis: Critical Studies in Gender, Culture \& Social Justice, 34 (2), 115-126.

[7] Collins, P. H. (1990). Black Feminist Thought: Knowledge, Consciousness, and the Politics of Empowerment. Boston: Unwin.

[8] Valdes, F. (1997). Beyond Sexual Orientation in Queer Legal Theory: Majoritarianism, Multidimensionality, and Responsibility in Social Justice Scholarship or Legal Scholars as Cultural Warriors. Denver University Law Review, 75, 1409.

[9] Van Herk, K. A., Smith, D., Andrew, C. (2011). Examining our privileges and oppressions: incorporating an intersectionality paradigm into nursing. Nursing Inquiry, 18 (1), 29-39. doi: http://doi.org/10.1111/j.1440-1800.2011.00539.x

[10] Hall, S. (Ed.) (1997). Representation: Cultural Representations and Signifying Practices. Vol. 2. Sage.

[11] Anthias, F. (2012). Hierarchies of social location, class and intersectionality: Towards a translocational frame. International Sociology, 28 (1), 121-138. doi: http://doi.org/10.1177/0268580912463155

[12] Winker, G., Degele, N. (2011). Intersectionality as multi-level analysis: Dealing with social inequality. European Journal of Women's Studies, 18 (1), 51-66. doi: http://doi.org/10.1177/1350506810386084

[13] Marais, H. (2011). South Africa pushed to the limit: The Political Economy of Change. London, New York: Zed Books, 566.

[14] Warner, L. R. (2008). A Best Practices Guide to Intersectional Approaches in Psychological Research. Sex Roles, 59 (5-6), 454-463. doi: http://doi.org/10.1007/s11199-008-9504-5

[15] Mamokhere, J. (2019). An exploration of reasons behind service delivery protests in South Africa: A case of Bolobedu South at the Greater Tzaneen Municipality. International Conference on Public Administration and Development Alternatives (IPADA).

[16] Netswera, F. G. (2014). The underlying factors behind violent municipal service delivery protests in South Africa. Journal of Public Administration, 49 (1), 261-273.

[17] Langa, M., Kiguwa, P. (2013). Violent masculinities and service delivery protests in post-apartheid South Africa: A case study of two communities in Mpumalanga. Agenda, 27 (1), 20-31. doi: http://doi.org/10.1080/10130950.2013.793897

[18] Carusa, B., Sommer, M. (2018). Addressing the Menstrual Needs of Women and Girls is Necessary to Achieve Gender Equality in Water and Sanitation Service Delivery. Equality in Water and Sanitation Services. Routledge, 176-191. doi: http:// doi.org/10.4324/9781315471532-10

[19] Kehler, J. (2001). Women and poverty: the South African experience. Journal of international women's studies, 3 (1), $41-53$.

[20] Joshi, D., Fawcett, B., Mannan, F. (2012). Sanitation for the urban poor: Gender Matters. Diverting the flow: gender equity and water in South Asia. Zubaan, 175-202.

[21] Mohlakoan, N., Dugard, J. (2009). More work for women : A Rights-based analysis of Women's aces to basic services in South Africa. South African Journal on Human Rights, 25 (3), 546-572. doi: http://doi.org/10.1080/19962126.2009.11865216

[22] Iheduru, O. C. (2004). Black economic power and nation-building in post-apartheid South Africa. The Journal of Modern African Studies, 42 (1), 1-30. doi: http://doi.org/10.1017/s0022278x03004452

[23] Mabuza, L. C. (1989). One Never Knows: An Anthology of Black South African Women Writers in Exile. Johannesburg: Skotaville.

[24] Southall, R. (2007). Ten Propositions about Black Economic Empowerment in South Africa. Review of African Political Economy, 34 (111), 67-84. doi: http://doi.org/10.1080/03056240701340365

[25] Department of Trade and Industry (dti) (2011). Towards an Enabling Environment for Department of Trade and Industry. Women Economic Empowerment in South Africa: Status Quo Report. Pretoria. Available at: https://www.empowerwomen. org/en/resources/documents/2014/11/towards-an-enabling-environment-for-womens-economic-empowerment-in-south-africa?lang=en

[26] Gumede, W. M. (2007). Thabo Mbeki and the Battle for the Soul of the ANC. Zebra, 496.

[27] Mbeki, M. (2009) Architects of Poverty. Johannesburg: Picador Africa.

[28] Enaifoghe, A. O., C. Maramura, T. (2019). The proficiency in gender representation towards realizing good administration in governance for South Africa. Journal of Gender, Information and Development in Africa, 8 (2), 223-242. doi: http:// doi.org/10.31920/2050-4284/2019/8n2a12

[29] Francis, B. B., Hasan, I., Sharma, Z. (2020). Are Female CFOs Different? Evidence from Gender Pay Gaps. doi: http:// doi.org/10.2139/ssrn.3631951

[30] Niyimbanira, F. (2016). Characterisation of time-related underemployment in a South African municipality: a case of Bushbuckridge, Mpumalanga province. International journal of social sciences and humanity studies, 8 (1), 116-132.

[31] Beukes, R., Fransman, T., Murozvi, S., Yu, D. (2017). Underemployment in South Africa. Development Southern Africa, 34 (1), 33-55. doi: http://doi.org/10.1080/0376835x.2016.1269634 
[32] Escalante, L. E., Maisonnave, H., Chitiga, M. R. (2020). Do South African fiscal reforms benefit women? Applied Economics, 53 (6), 719-729. doi: http://doi.org/10.1080/00036846.2020.1813247

[33] Bosch, A., Barit, S. (2020). Gender pay transparency mechanisms: Future directions for South Africa. South African Journal of Science, 116 (3/4). doi: http://doi.org/10.17159/sajs.2020/6772

[34] Musetsho, M., Isac, N., Dobrin, C. (2021). Gender Inequalities in the Workplace: Case Study of South Africa. Management and Economics Review, 6 (1), 70-81. doi: http://doi.org/10.24818/mer/2021.06-06

[35] Bussin, M., Christos, D. (2016). Re-evaluate your gender pay gap: hot button-pay gap. HR Future, 2016 (9), $32-33$.

[36] Chitiga, M., Henseler, M., Mabugu, R. E., Maisonnave, H. (2021). How COVID-19 Pandemic Worsens the Economic Situation of Women in South Africa. The European Journal of Development Research. doi: http://doi.org/10.1057/s41287-021-00441-w

[37] Eagly, A. H., Carli, L. L. (2018). Women and the labyrinth of leadership. Contemporary Issues in Leadership. Routledge, 147-162. doi: http://doi.org/10.4324/9780429494000-17

[38] Ibarra, H., Carter, N. M., Silva, C. (2010). Why men still get more promotions than women. Harvard business review, 88 (9), 80-85.

[39] Ndinda, C., Okeke-Uzodike, U. (2012). Present but absent: Women in business leadership in South Africa. Journal of international women's studies, 13 (1), 127-145.

[40] Mathur-Helm, B. (2006). Women and the glass ceiling in South African banks: an illusion or reality? Women in Management Review, 21 (4), 311-326. doi: http://doi.org/10.1108/09649420610667028

[41] Women in power: what do the statistics say? (2017). Statistics South Africa (StatsSA). Available at: http://www.statssa.gov. $\mathrm{za} / \mathrm{p}=10325$

[42] Kobus-Olawale, J., Schachtebeck, C., Dhanpat, N. (2021). Investigating career progression experiences of women into top management at a South African bank. EUREKA: Social and Humanities, 3, 28-40. doi: http://doi.org/10.21303/ 2504-5571.2021.001778

[43] Makgetla, N. S. (2004). The post-apartheid economy. Review of African Political Economy, 31 (100), 263-281. doi: http:// doi.org/10.1080/0305624042000262284

[44] Loss of income resulting from the COVID-19 pandemic may lead to higher levels of food insecurity SA (2020). Statistics South Africa (StatsSA). doi: http://www.statssa.gov.za/?p=13327

[45] Abbas, H., Mama, A. (2014). Feminism and pan-Africanism. Feminist Africa 19 Pan-Africanism and Feminism, 1.

[46] Waylen, G. (2007) Engendering Transitions: Women's Mobilization, Institutions, and Gender Outcomes. Oxford: Oxford University Press, 241.

[47] Hassim, S. (2006). Women's Organizations and Democracy in South Africa: Contesting Authority. University of Wisconsin Press, 355.

[48] COVID-19 to Add as Many as 150 Million Extreme Poor by 2021 (2021). World Bank. Available at: https://www.worldbank. org/en/news/press-release/2020/10/07/covid-19-to-add-as-many-as-150-

[49] Patel, L., Graham, L. (2012). How broad-based is broad-based black economic empowerment? Development Southern Africa, 29 (2), 193-207. doi: http://doi.org/10.1080/0376835x.2012.675692

[50] With increased levels of joblessness and unemployment as the result of a global pandemic (2020). Statistics South Africa (StatsSA).

[51] Bassett, C. (2008) 'South Africa: Revisiting Capital's "Formative Action", Review of African Political Economy, 35 (116), 185-202. doi: http://doi.org/10.1080/03056240802193804

How to cite: Joseph, J. (2021). Post-apartheid South Africa's exacerbated inequality and the Covid-19 pandemic: intersectionality and the politics of power. EUREKA: Social and Humanities, 6, 69-78. doi: http://doi.org/10.21303/2504-5571.2021.002099 